\title{
Studie hodnocení účinku prírodě blízkých opatření v povodí Olešné u Pelhřimova pomocí modelů BILAN, HEC-HMS a HYPE
}

\author{
ADAM VIZINA, LUDĚK STROUHAL, MIRIAM DZURÁKOVÁ, VOJTĚCH MORAVEC, EVA MELIŠOVÁ
}

Klíčová slova: přírodě blízká opatření - revitalizace - hydrologická bilance - extrémní odtoky látkové toky v povodí - malé povodí - hydrologické modelování

\section{SOUHRN}

V rámci několika výzkumných úkolů pro MŽP, zejména $v$ oblasti problematiky zvládání sucha, byl vypracován katalog prírodě blízkých opatření a vytipovány typické lokality pro jejich aplikaci. Účinek navržených opatření na různé aspekty hydrologického režimu povodí byl hodnocen prostřednictvím modelových nástrojů. Předložený příspěvek prezentuje výsledky tohoto hodnocení na jedné z typických lokalit - povodí Olešné u Pelhřimova. Ovlivnění dlouhodobého odtokového režimu bylo simulováno prostřednictvím modelu BILAN, vliv na extrémní odtoky byl hodnocen $v$ modelu HMS a potenciální změny v látkových tocích byly vymezeny formou citlivostní analýzy v modelu HYPE. V prípadě dlouhodobé bilance byl identifikován lehce pozitivní vliv ve srážkově bohatých letních měsících a lehce negativní vliv ve zbytku roku. Z hlediska extrémních odtoků mají navržená opatření potenciál prakticky zcela zadržet odtokovou odezvu na srážky s dobou opakování 2-5 let, u vyšších pak byla prokázána schopnost značné redukce kulminačních průtoků i objemu odtoku, prípadně jejich zpoždění. Citlivostní analýza látkových toků ukázala, že přechod z orné půdy na luční porost zapríčiní pokles koncentrace dusíku a rozpustného fosforu, nikoliv však pevného fosforu. Dávkování hnojiv má vliv pouze na fosfor v obou fázích a jejich výsledná koncentrace kladně koreluje s mírou dávkování, dusík zůstává neměnný.

\section{ÚVOD}

V předložené studii je zjednodušeně kvantifikován vliv prírodě blízkých retenčních opatření na hydrologický systém v povodí Olešné u Pelhřimova. V povodí byla navržena řada dílčích opatření vybraných z katalogu, který byl sestaven v rámci úkolu pro MŽP. Cílem studie bylo vyhodnocení komplexního dopadu systému opatření jak na dlouhodobý hydrologický režim, tak na extrémní odtoky a látkové toky v povodí. Navržený postup umožňuje orientační stanovení hodnot parametrů modelů BILAN, HMS a HYPE pro povodí, jehož hydrologický systém je ovlivněn zejména plošnými, případně několika liniovými či bodovými prírodě blízkými opatřeními.

Předpokládaným pokračováním této studie je ověření modelových výsledků pomocí fyzického monitoringu. Ten by měl vyhodnotit skutečný dopad navržených opatření na simulované aspekty hydrologického režimu. Takové hodnocení lze však provést pouze srovnáním stávajícího stavu se stavem dosaženým rádově 10 let po realizaci jednotlivých opatření v povodí, což vyžaduje trvalou údržbu a podporu komplexního monitoringu povodí.

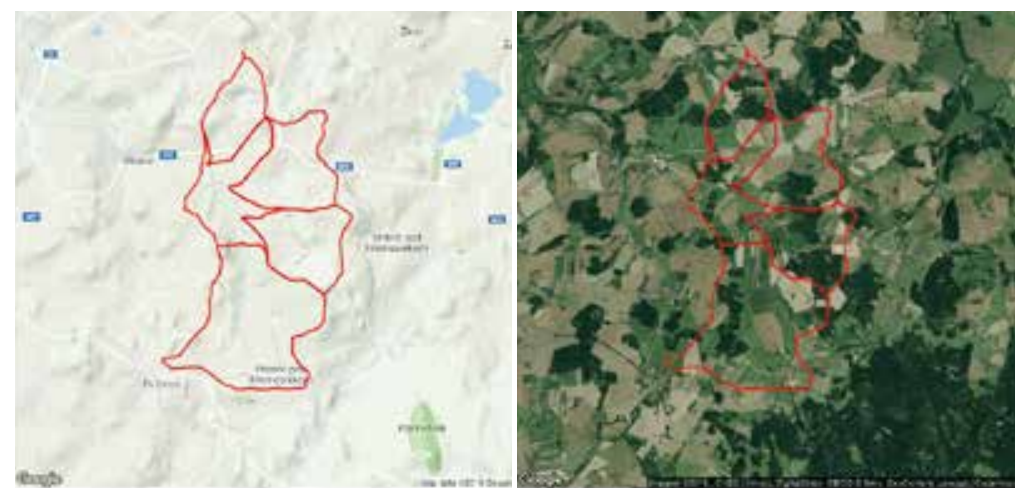

Obr. 1. Terénní mapa a letecký snímek lokality s naznačeným dělením na dílčí povodí pro modelování v HMS

Fig. 1. Terrain map and ortophotograph with subcatchment boundaries used for modelling in HMS

\section{CHARAKTERISTIKA LOKALITY A NAVRŽENÁ OPATŘENÍ}

Povodí posuzovaného povodí Olešné se nachází 4 km východně od Pelhřimova v kraji Vysočina. Část povodí s plánovanými opatřeními je dána závěrovým profilem umístěným $100 \mathrm{~m}$ pod zaústěním bezejmenného pravostranného prítoku mezi průmyslovým a zemědělským areálem nad obcí Olešná. Jeho rozloha je 8,9 km², průměrná nadmořská výška $592 \mathrm{~m}$ n. m. a průměrný sklon území 7,6 \% (odvozeno z DMR4G). Jak je patrné z obr. 1, charakter povodí je spíše vrchovinný s převažujícím podílem zemědělské půdy a jen drobnou venkovskou zástavbou.

Jednou z nejjednodušších charakteristik odtokového režimu povodí zahrnující vliv hydrologických charakteristik půd i půdního pokryvu je číslo odtokové křivky CN. Na obr. 2 jsou zobrazeny jeho hodnoty pro tři úrovně nasycení povodí podle indexu předchozích srážek CN I, CN II a CN III pro současné podmínky bez zahrnutí navrhovaných opatření.

Klimatologické veličiny byly na povodí Olešné vyhodnoceny pro tři časová období: 1961-1990, 1991-2005 a 2006-2015 a jsou znázorněny formou box-plotů na obr. 3 a 4. Jednotlivá období jsou od sebe barevně odlišena. Na obr. 3 Ize vidět, že z pohledu průměrných měsíčních úhrnů bylo prostřední hodnocené období 1991-2005 srážkově spiše nadprůměrné a současný stav se priblížil zpět podmínkám v prvním období 1961-1990. 


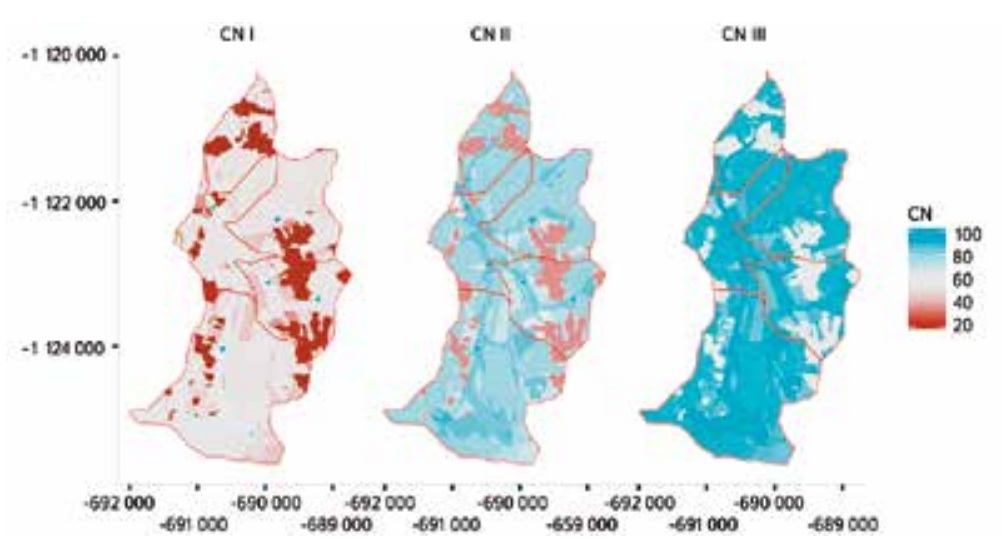

Obr. 2. Rozložení hodnot CN v povodí Olešné pro různé počáteční stavy nasycení Fig. 2. CN values distribution in Olešná stream catchment for different antecedent precipitation indices

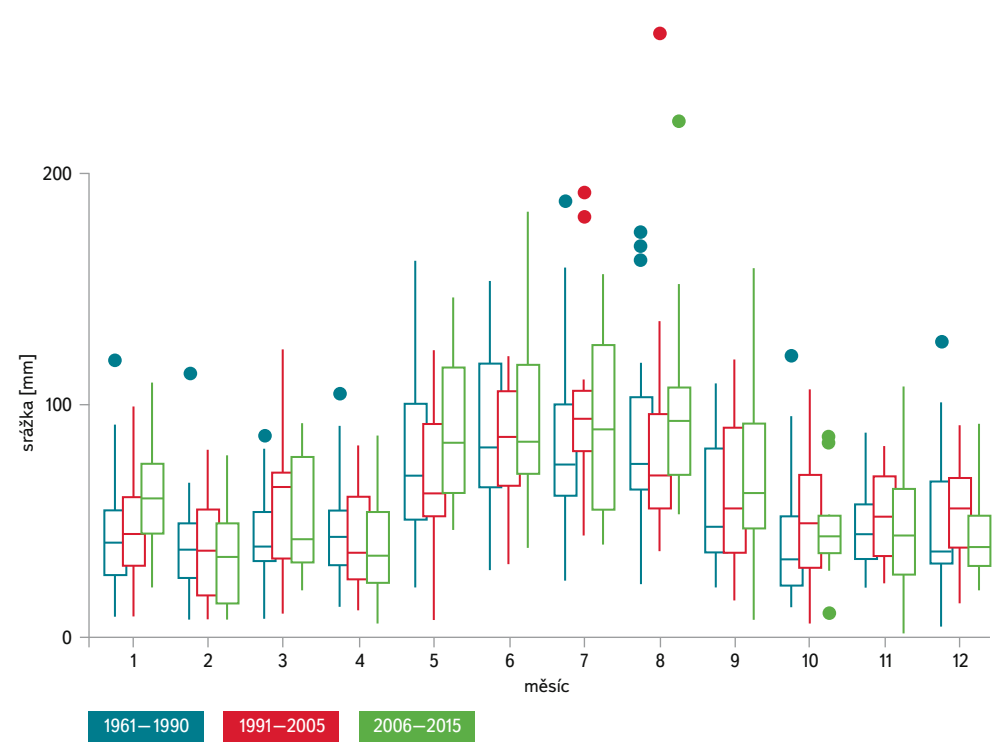

Obr. 3. Měsíční srážkové úhrny za období 1961-1990, 1991-2005 a 2006-2015 ve formě box-plotů

Fig. 3. Monthly precipitation means in 1961-1990, 1991-2005 and 2006-2015 periods in the box-plot form

Z hlediska teplot vzduchu za období 1961-2015 byly hodnoceny průměrné měsíční teploty za shodná období jako v prrípadě srážek, výsledné grafy jsou znázorněny na obr. 4. Můžeme na něm pozorovat zřetelný nárůst teplot, a to především v zimních a letních měsících. Tento nárůst znamená snížení zásoby vody ve sněhu v zimním období, dřivější jarní tání a zároveň nižší jarní odtoky a v létě výrazný nárůst evapotranspirace.

Statistická významnost trendu měsíčních srážkových úhrnů a teplot vzduchu za celé období 1961-2015 byla posouzena Mann-Kendalovým testem. Výsledky jsou zobrazeny na obr. 5. Lze pozorovat statisticky významný nárůst teploty s vysokou hladinou významnosti především v měsících na počátku vegetačního období, kdy naopak srážkové úhrny mají spíše klesající, ač statisticky málo významnou, tendenci. Celkově srážkové úhrny spíše lehce rostou.

Kromě dlouhodobých klimatických charakteristik byly za účelem posouzení ovlivnění extrémních odtoků odvozeny šestihodinové návrhové srážky s dobami opakování 2-50 let podle metodiky [1]. Úhrny návrhových srážek jsou zobrazeny na obr. 6.

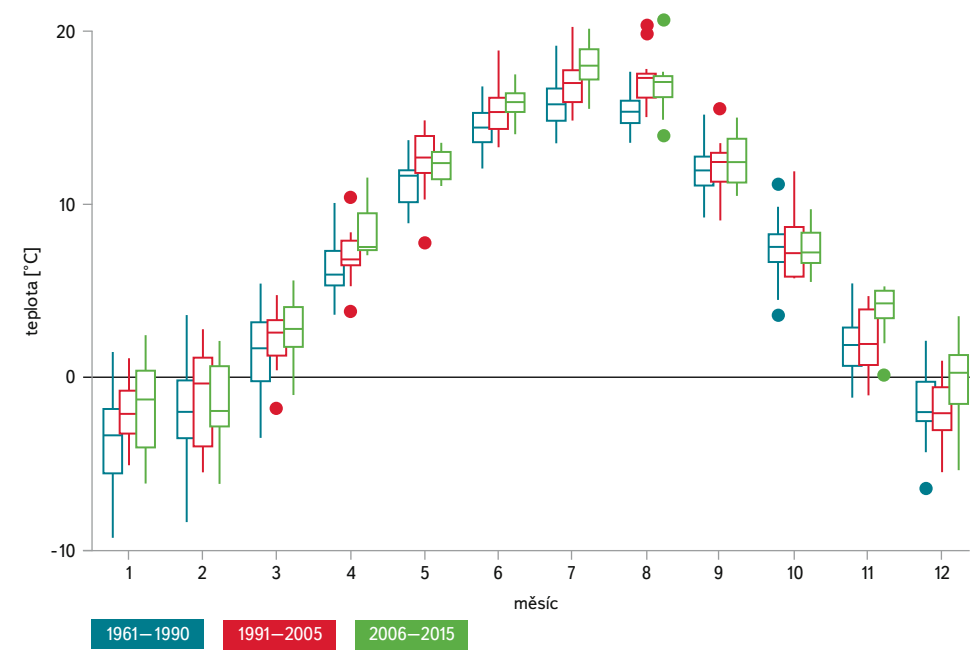

Obr. 4. Průměrné měsíční teploty vzduchu za období 1961-1990, 1991-2005 a 2006-2015 ve formě box-plotů

Fig. 4. Monthly temperature means in 1961-1990, 1991-2005 and 2006-2015 periods in the box-plot form

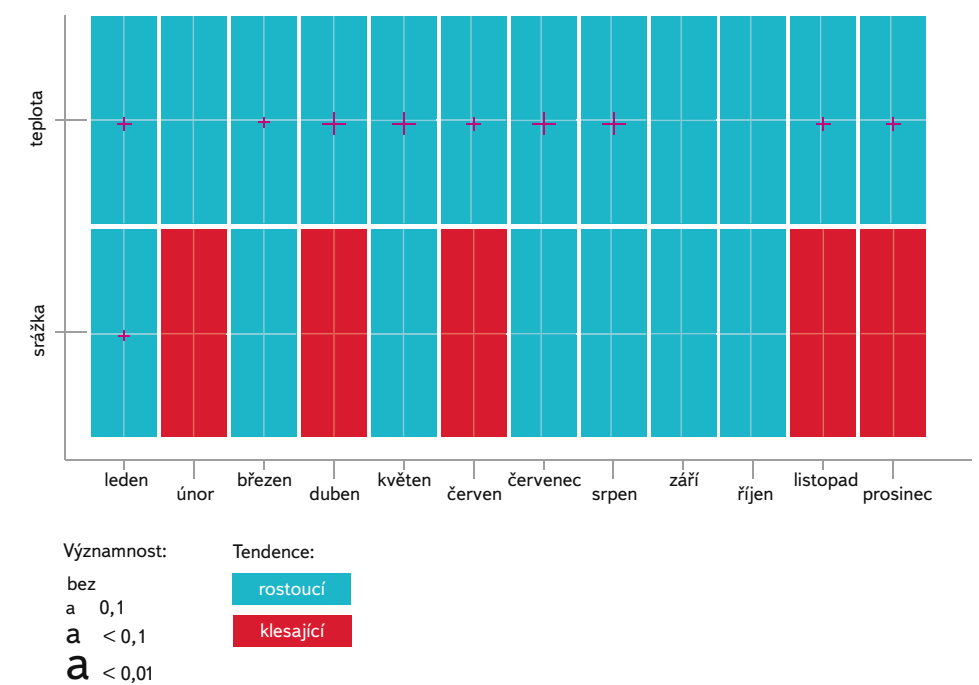

Obr. 5. Analýza trendů měsíčních úhrnů srážek a průměrných teplot vzduchu pomocí Mann-Kendallova testu

Fig. 5. Trend analysis of monthly means of temperatures and precipitation using MannKendall test

Průběh srážky významně ovlivňuje hydrologickou odezvu povodí. Rozmanitost průběhu prírodních srážek je velmi značná a z těchto důvodů byly použity typizované návrhové šestihodinové hyetogramy, průběh jejich pětiminutových intenzit je znázorněn na obr.7 nahoře. Typy hyetogramů jsou označeny písmeny $A$ až F, kdy typy $A, B, E$ a F mají jednoduchý průběh, typy $C$ a D představují srážky se dvěma vrcholy. Pravděpodobnost výskytu návrhové srážky pro danou dobu opakování N v řešené lokalitě je zobrazena na obr. 7 dole. 


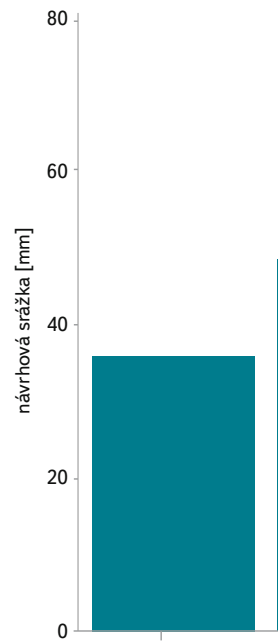

$\mathrm{H} 2$

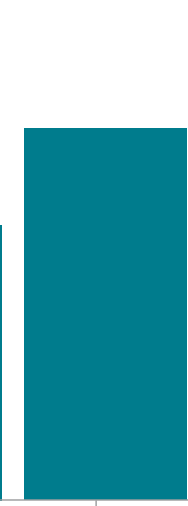

H5

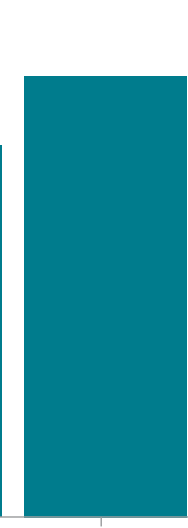

$\mathrm{H} 10$

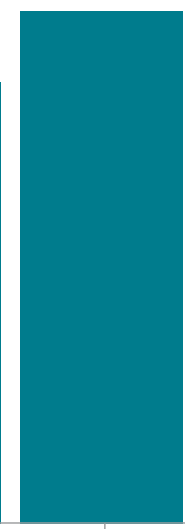

$\mathrm{H} 20$

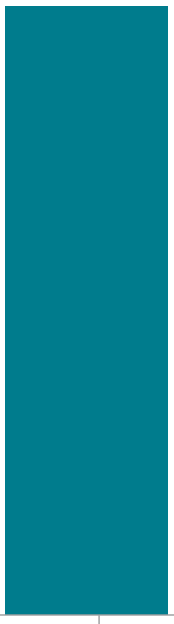

$\mathrm{H} 50$
Obr. 6. Úhrny šestihodinové návrhové srážky s dobami opakování 2, 5, 10, 20 a 50 let Fig. 6. Six-hour design rainfall totals of return periods 2, 5, 10, 20 and 50 years
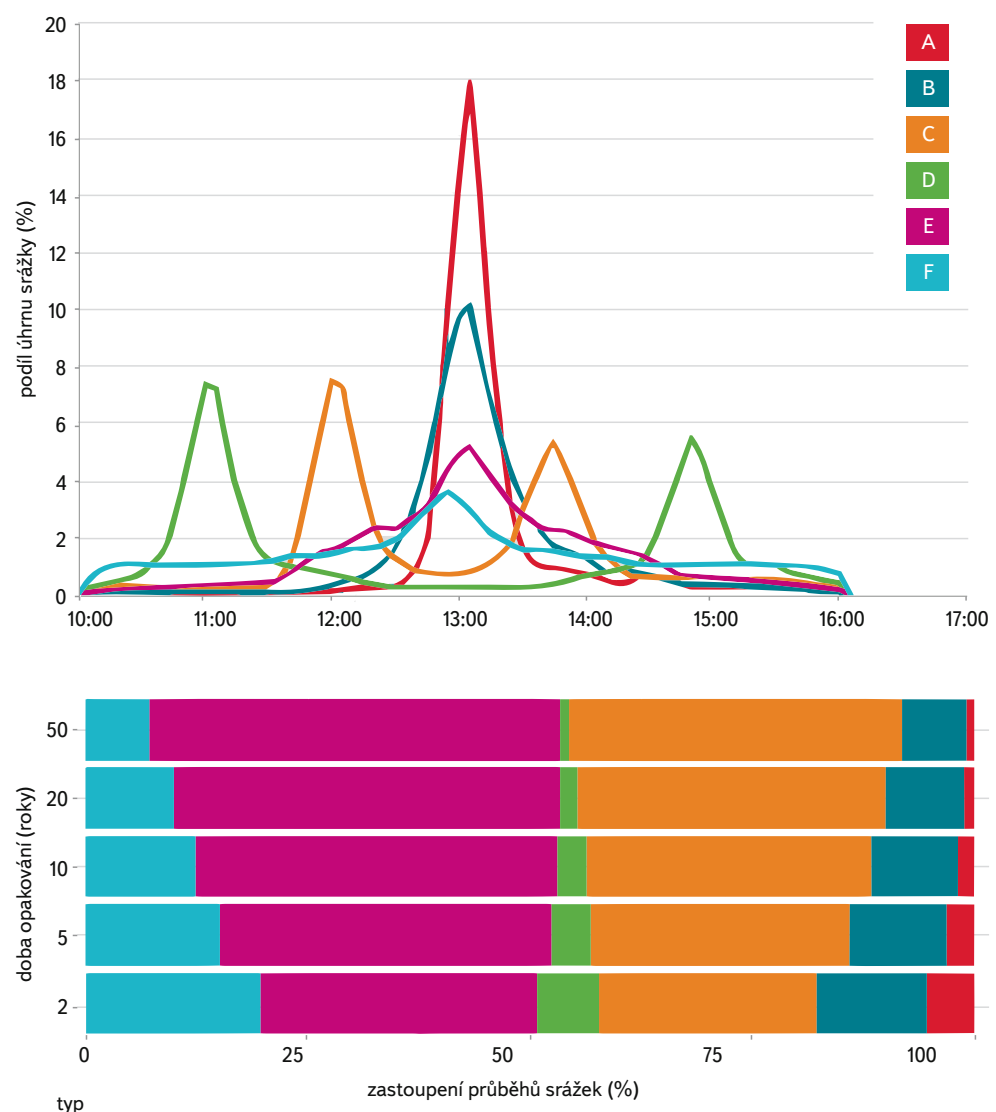

\section{A $B$ B C C D D E F F}

Obr. 7. Návrhové hyetogramy srážky v rozlišení 5 minut (nahoře) a pravděpodobnost jejich výskytu v povodí Olešné (dole)

Fig. 7. Design rainfall hyetographs of 5 minutes resolution (top panel) and their occurrence frequency in the Olešná stream catchment (bottom panel) $\checkmark$ povodí Olešné byla navržena kombinace technických a prírodě blízkých opatření. Schematicky je znázorněna na obr. 8 a skládá se z následujících dílčích opatření:

- Vodní nádrž

Nová vodní nádrž byla navržena jako protipovodňová ochrana obce Plevnice, s dostatečným retenčním potenciálem pro transformaci povodňové viny. Nádrž může být realizována jako suchá nebo s částečným nadržením. Konečný typ nádrže vyplyne až z podrobně vyhotovené dokumentace nádrže podle potřeby a kapacity sběrné plochy povodí nad nádrží. Při současné podrobnosti řešení bylo vyčísleno, že pokud by se jednalo o suchou retenční průtočnou nádrž, dokázala by zachytit objem celé stoleté povodňové vlny. Zároveň by ale v prípadě provedení s částečným nadržením mohla v období sucha zajištovat akumulaci vody $v$ krajině a napomáhat k infiltraci povrchového odtoku.

- Opatření na stávající vodní nádrži

Návrh předpokládá rekonstrukci objektů, hráze nebo odbahnění podle detailní technické prohlídky, místních podmínek a potřeb.

- Revitalizace vodního toku a nivy

Účelem tohoto opatření je přibližit morfologii koryta vodního toku směrem k prírodním podmínkám, zajistit migrační zprůchodnění prííných objektů, obnovit proces zaplavování nivy při zvýšených průtocích atd. Návrh předpokládá s revitalizací v celkové délce až 4600 m.

- Agrotechnická opatření

Cílem agrotechnických opatření je maximální možné zkrácení času, po který není půda chráněna vegetačním pokryvem, a zlepšení půdních vlastností prostřednictvím alternativních způsobů obdělávání. Hlavní funkcí je ochrana půdy, tedy zamezení degradace pưdy a snížení erozního smyvu. Celkově je cíleno na zlepšení vodního režimu v pưdě. Mezi plošná agrotechnická opatření patří např. technologie ochranného zpracování půdy, hrázkování, důlkování, mulčování, setí do krycí plodiny apod.

- Trvalé zatravnění

Toto opatření představuje krajní zásah do existujícího způsobu hospodaření a bývá obvykle navrhováno na mělkých a silně erozně ohrožených půdách s vyšším sklonem. Plně zapojený travní porost je neúčinnější protierozní ochrana, chrání půdu před degradací a celkově napomáhá zlepšení vodního režimu v půdě.

\section{METODIKA}

Navržená opatření jsou značně rozmanitá z hlediska velikosti, dimenze (bodová, liniová až plošná) či účelu, tedy prírodního procesu, který mají ovlivňovat. Univerzální a ucelené hodnocení celého systému opatření tedy není dobře dosažitelné. V rámci řešeného projektu bylo dále posuzováno celkem 20 lokalit s omezenými datovými podklady, proto ani př́liš detailní modelování nejmodernějšími prostředky nebylo možné aplikovat. Proto byly vybrány tři aspekty hydrologického chování povodí, jejichž ovlivnění realizovanými opatřeními bylo samostatně posuzováno různými metodami a prostředky:

1. změny $v$ dlouhodobém odtokovém režimu byly posouzeny $v$ modelu BILAN $\checkmark$ kombinaci s metodou SCS-CN,

2. ovlivnění extrémních odtoků bylo simulováno modelem HMS v kombinaci s metodou SCS-CN,

3. možný vliv opatření na látkové toky v povodí byl kvantifikován pomocí modelu HYPE. 


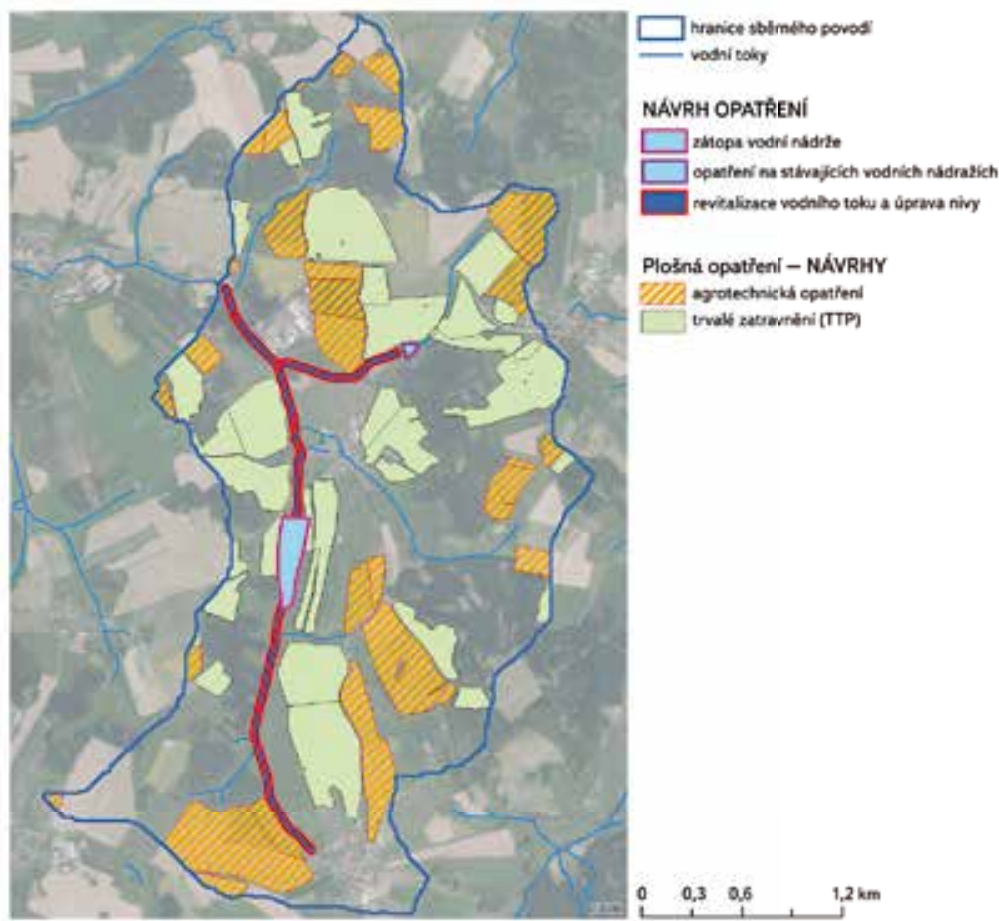

Obr. 8. Navržená technická a prírodě blízká opatření v povodí Olešné

Fig. 8. Design system of natural restoration measures in the Olešná stream catchment

Metoda SCS-CN, aplikovaná ve dvou ze tři uvedených posouzení, je v ČR známa jako metoda odtokových křivek. Metoda je celosvětově oblíbená vzhledem ke své jednoduchosti a stále se hojně využívá, přestože má mnohá teoretická omezení. Používá se ke stanovení velikosti prímého odtoku (povrchový odtok plus rychlý podpovrchový odtok) na základě znalosti intenzity úhrnu prríčinné srážky a hydrologických vlastností půdy a půdního pokryvu. Metoda byla testována a ověřena mnohými výzkumy a studiemi odtokových poměrů. $\checkmark$ malých povodích existuje dobrá korelace mezi naměřenou výškou odtoku a výškou odtoku stanovenou metodou čísel SCS-CN. Průměrné hodnoty CN pro libovolné území lze snadno určit z běžných datových podkladů s využitím nástrojů GIS. Metoda odtokových křivek může být použita při navrhování vodohospodářských opatření a drobných staveb nacházejících se v ploše povodí nebo na vodních tocích do velikosti povodí $5 \mathrm{~km}^{2}$ [2].

Metoda SCS-CN byla odvozena na zemědělsky využívaných povodích, jejichž plocha není větší než 10 km². Zejména pro velká povodí je potřeba u výsledků výpočtu počítat se značnými nepresnostmi. Dalším faktorem ovlivňujícím presnost metody zejména pro extremální úlohy je časové rozložení intenzit srážek, které metoda CN nezohledňuje, nebot pro jakýkoliv zvolený průběh srážky dává totožný objem odtoku. Průměrná hodnota CN se pro konkrétní území určuje jako plošný vážený průměr hodnot pro jednotlivé pozemky. Tato detailní čísla se stanovují obvykle podle metodických tabulek. Pro potřeby projektu byly využity tabulkové hodnoty CN převzaté z originální metodiky [3] a pro netabelované kategorie půdního pokryvu (PP), jako např́iklad pro agrotechnická opatření, byly z těchto originálních hodnot odvozeny nové podle odborného posouzení charakteru opatření. Pro přiřazení CN k elementárním odtokovým plochám je potřeba znát druh PP a hydrologickou skupinu půd (HSP). Datová vrstva PP byla odvozena ze ZABAGED se zjednodušením na deseti kategoriích povrchu. Pro určení hydrologické skupiny půd byla využita volně dostupná data BPEJ pro zemědělskou pưdu a vrstva Lesních typů od ÚHÚL překlasifikovaná na HSP podle metodiky [4]. Tabelované hodnoty CN se zpravidla vztahují k průměrnému vlhkostnímu stavu danému indexem predchozí srážky (IPS2), pro potřeby extremálního modelování byly hodnoty CN II dále přepočteny i pro nasycený stav daný indexem IPS3. Z hodnot CN II a III byly dále odvozeny príslušné hodnoty potenciální retence, které byly kromě samotného určení odtokové výšky v modelu HMS použity i pro stanovení parametru Spa v hydrologickém modelu BILAN. Prostřednictvím rozdílných hodnot CN pro původní stav povodí a stav po návrhu opatření se do modelů promítne efekt části posuzovaných opatření. Některá další specifická opatření byla v jednotlivých modelech zahrnuta jiným způsobem, podrobněji jsou popsána v následující části metodiky specificky pro konkrétní model.

\section{Opatření a hydrologický model BILAN}

Pro modelování hydrologické bilance byl použit model BILAN, který je vyvíjen více než 15 let na oddělení hydrologie Výzkumného ústavu vodohospodářského T. G. Masaryka, v. v. i. Model počítá v denním či měsíčním časovém kroku chronologickou hydrologickou bilanci povodí či území. Vyjadřuje základní bilanční vztahy na povrchu povodí, v zóně aerace, do níž je zahrnut i vegetační kryt povodí, a v zóně podzemní vody. Jako ukazatel bilance energie, která hydrologickou bilanci významně ovlivňuje, je použita průměrná teplota vzduchu. Výpočtem se modeluje potenciální evapotranspirace, územní výpar, infiltrace do zóny aerace, průsak touto zónou, zásoba vody ve sněhu, zásoba vody v půdě a zásoba podzemní vody. Odtok je modelován jako součet tři složek: dvě složky prímého odtoku (zahrnující i hypodermický odtok) a základní odtok [5]. Pro modelování hydrologické bilance byla použita měsiční verze modelu, která má osm parametrů. Pro modelovaný odtok má klíčový význam parametr Spa, který udává retenci půdy $v$ povodí a parametr Grd udávající odtok ze zásob podzemních vod (základní odtok).

Vstupem do modelu jsou denní či měsíční veličiny:

- srážkové úhrny ( $\mathrm{mm})$,

- průměrné teploty $\left({ }^{\circ} \mathrm{C}\right)$,

- průměrná vlhkost vzduchu (\%),

- pozorované odtokové výšky (mm),

- užívání vody (odběry, vypouštění),

- potenciální evapotranspirace (mm).

Pro hodnocení změn v chování povodí způsobené realizací navržených opatření bylo využito přístupu předchozí práce [6], v níž byl pro stanovení parametru Spa identifikován následující lineární model na základě krokové regrese:

$$
S p a=0,71 \times S 3+88,91 D d-8,89 S t+65,76
$$
kde S3 je maximální retence pro III. typ předchozích vláhových podmí- nek (mm),
Dd hustota říční sítě povodí $\left(\mathrm{km} / \mathrm{km}^{2}\right)$,
St průměrný sklon říční sítě (\%).

Celý soubor představuje statisticky významné vstupní veličiny, což bylo potvrzeno výsledky F testu a t-testů. 
Pro parametr Grd byl krokovou regresí stanoven následující lineární model:

$$
\text { Grd }=0,02 \times S t-0,003 \text { Smax }+0,23
$$

kde soubor deskriptorů je tvořen průměrným sklonem říční sítě St (\%) a maximálním lokálním sklonem v povodí Smax (\%). Opět výsledný model obsahuje statisticky významné vysvětlující geomorfologické veličiny podle $F$ testu a t-testů.

Pro samotné stanovení parametrů modelu byly vypočteny pro jednotlivá povodí hydrogeomorfologické charakteristiky jako:

- hustota ríční sítě,

- průměrný sklon říční sítě,

- sklonitost povodí,

ze kterých byl následně odvozen parametr Spa vyjadřující retenční kapacitu povodí. Pro samotné modelování byla využita časová řada v měsíñním časovém kroku za období 1961-2015 tak, aby obsahovala co největší variabilitu hydrologického režimu.

\section{Opatření v modelu HMS}

HMS je veřejně dostupný a bezplatně poskytovaný nástroj vyvíjený v americkém Hydrologic Engineering Center. Jedná se o softwarové prostředí umožňující využití řady výpočetních modelů a metod, z nichž asi nejrozšířenější je metoda odtokových křivek SCS-CN. Velkou nevýhodou této metody je, že hodnota výsledné odtokové výšky není závislá na časovém rozložení příčinné srážky. Odtoková výška ze dvou srážek s totožným úhrnem ale s prưběhy např. v podobě rovnoměrného deště nízké intenzity a prívalovou srážkou je rovněž totožná, což neodpovídá fyzikálním principům tvorby přímého odtoku. Z tohoto důvodu je třeba opatrnosti při interpretaci výsledků modelu, nebot’ objemy odtoku i kulminační průtoky mohou být u přivalových srážek podhodnoceny.

Pro určení výsledného odtoku z př́činné srážky je nutné hyetogram efektivní srážky získaný metodou SCS-CN transformovat do odtokové odezvy. V HMS Ize k tomuto účelu využít opět řadu metod, nejznámější je pravděpodobně metoda jednotkového hydrogramu. Jedná se o jedno- či víceparametrickou matematickou funkci rozkládající jednorázový srážkový impulz do odtokové viny. Parametry určující tvar hydrogramu lze odvodit často z hydromorfologických charakteristik povodí, např. maximální délky odtokové dráhy a průměrného sklonu povodí.

Pro určení dopadů navržených opatření na extrémní odtoky byly v HMS sestaveny modely povodí ve dvou variantách - před a po realizaci opatření. $\checkmark$ prípadě povodí Olešné sestával model celkem z pěti dílčích podpovodí. Pro určení objemu odtoku byly použity průměrné hodnoty CN II pro většinu druhů půdního pokryvu, u orné půdy pak byly použity hodnoty pro nejvíce rizikový scénáŕ, tedy holý úhor. Pro transformaci odtoku byla zvolena metoda SCS jednotkového hydrogramu, která vyžaduje pouze jeden parametr - dobu zpoždění. Ta byla určena z hodnoty CN II, maximální délky odtokové dráhy a průměrného sklonu povodí.

Model povodí Olešné byl zatí̌en sadou šestihodinových návrhových srážek s dobou opakování $\mathrm{N}=2,5,10,20$ a 50 let, a to $v$ několika variantách průběhu intenzity srážky. Prostorové rozložení návrhové srážky bylo uvažováno homogenní, tedy totožný úhrn pro všechna podpovodí. Tento postup je v souladu se zjištěním Řezáčové [7], že extrémní úhrny je třeba redukovat podle zasažené plochy približně od 20 km². Návrhové úhrny byly získány pomocí webové processingové služby (WPS) poskytované pracovištěm ČVUT (rain.fsv.cvut.cz).
Krátkodobé srážky, které jsou nejčastější příčinou extrémních odtoků z malých povodí, se vyznačují značnou časovou variabilitou průběhu. Müller a kol. [8] odvodili na území ČR šest typických průběhů šestihodinových srážek A-F včetně četnosti jejich výskytu v závislosti na poloze a době opakování. Stejně jako návrhové úhrny byly tyto četnosti výskytu ve všech povodích získány s využitím zmíněné WPS služby. Pro modelování v HMS pak byly vybrány typy průběhů s významným zastoupením (více než 17 \%) při dvou a více dobách opakování, v povodí Olešné se jedná konkrétně o dva průběhy typu $C$ a E, jak ukazuje graf na obr. 7 dole. Jako návrhový stav byl uvažován průměrný stav nasycení daný indexem předchozího nasycení Il, což je v souladu s metodikou [1].

$\checkmark$ modelování odezvy povodí na extrémní srážky byl zohledněn výskyt navrženého retenčního prvku - suché nádrže. Výpočet transformace umožňuje HMS na základě definice výpustních objektů a křivek zásobní funkce nádrže či zatopených ploch. Objekty byly specifikovány orientačně na základě dimenzí typických pro daný typ stavby. Zásobní funkce nádrže byly odvozeny v GIS na základě DMT a mapových podkladů.

Posledním typem modelovaného opatření je revitalizace vodního toku a přilehlé nivy. Pro transformaci odtokové viny ve vodním toku využívá HMS jednoduchou hydrologickou metodu Muskingum-Cunge. Pro definici transformace je nutné zadat délku a sklon řícních úseků, geometrii koryta a jeho hydraulické drsnosti. Délka a sklon byly určeny v GIS, geometrie byla definována zjednodušeně jako jednoduché kapacitní lichoběžníkové koryto pro ovlivněné úseky toku a jako složené lichoběžníkové koryto s širokými bermami pro prírodě blízké úseky. Jako príslušné výchozí drsnosti byly použity hodnoty 0,025 , resp. 0,025 či 0,03. Pro úseky s navrženou revitalizací byla v modelu o $30 \%$ prodloužena délka úseku toku, príslušným způsobem snížen podélný sklon, přičný profil změněn na prírodě blízký (mělká kyneta a široké rozlivné bermy) a zvýšena hydraulická drsnost na 0,03 a 0,035.

\section{Modelování opatření v HYPE}

HYPE je semidistribuovaný open-source hydrologický model [9], který slouží k simulaci látkových toků v rámci povodí. Pracuje na bázi fragmentace povodí na podpovodí, která jsou dále rozdělena do skupin hydrologicky responzivních jednotek (HRJ), které jsou výsledkem kombinace rastrových vrstev, jmenovitě vrstvy digitálního modelu terénu, vrstvy sklonitosti, vrstvy krajinného krytu, vrstvy základních hydropedologických ukazatelů (hloubka hydrologicky aktivní vrstvy půdy a skeletovitost půdy) a volitelně v rámci modelování kvality vody vrstvy plodinových map, popř. drenážních systémů. Jednotlivé HRJ mají unikátní hydrologický režim, jež je ovládán př́ślušnými parametry modelu. HRJ vstupují do modelu ve formě procentuálního zastoupení každé HRJ v rámci jednotlivých povodí. Model uvažuje až tři půdní vrstvy s rozdílnými hloubkami pro přesnější simulaci pohybu nutrientů půdou. Model pracuje se třemi skupinami parametrů, které jsou vázány bud’ globálně, nebo na druh krajinného pokryvu, nebo na typ půdy.

Kromě zmiňovaných rastrových vstupů jsou dále vstupem do modelu charakteristiky vodních děl, zejména těch manipulovaných, jmenovitě hloubka, objem, plocha, typ vodní nádrže, průměrný odtok z nádrže, minimální zůstatkový odtok z nádrže a řada dalších. Vstupem do modelu je také procentuální zastoupení vodních ploch na povodí, které bylo odvozeno z vektorové vrstvy nádrží z databáze DIBAVOD. Stejně tak délka hlavního toku a délka vedlejších toků. Protože na experimentálních lokalitách nejsou k dispozici údaje o průtocích ani záznamy o kvalitě vody, byly vybrány analogony (povodí s podobnými charakteristickými vlastnostmi, která měla k dispozici bud' měření průtoků, nebo údaje o kvalitě vody, a na která byl model kalibrován), na které byly přeneseny parametry modelu z experimentálních lokalit. Poněvadž zatím nebylo známo uskupení pěstovaných rostlin $v$ daných experimentálních lokalitách, byly aplikovány standardní hodnoty pro obecnou úzkořádkovou obilovinu. 


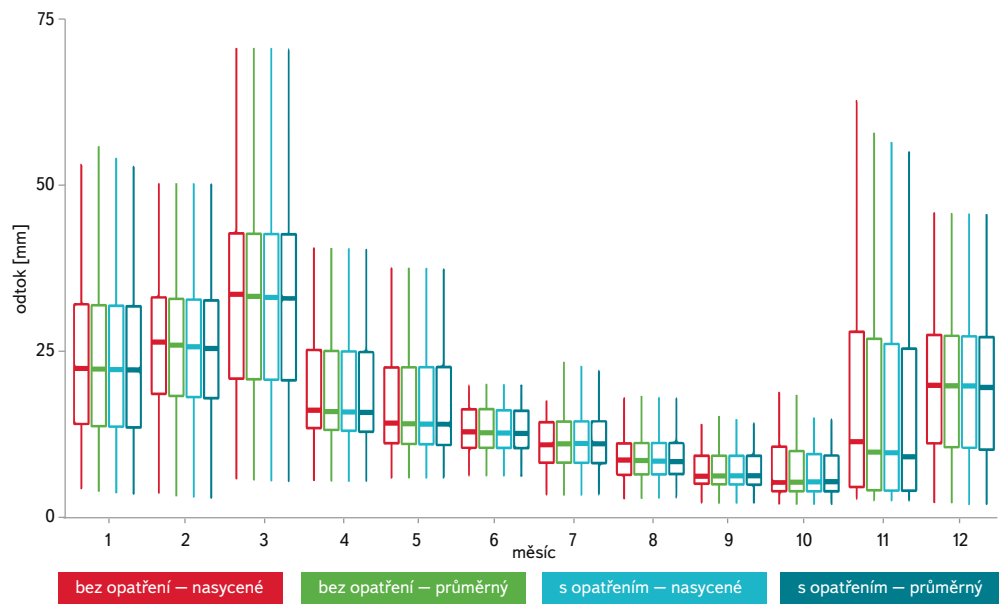

Obr. 9. Průměrné měsíční odtokové výšky ve formě box-plotů pro jednotlivé varianty hodnocení

Fig. 9. Monthly average runoff heights in the box-plot form according to modelled scenario

Z důvodu chybějících údajů pro jednotlivé lokality bylo modelování vlivu adaptačních opatření na jakost vody provedeno formou citlivostní analýzy vnitřních komponent modelu, které lze považovat za formy některých adaptačních opatření. Zmiňovanými komponentami byly:

— změna struktury půdy: uvažována záměna jemnozrnné půdy za půdu hrubozrnnou, a to $\vee 5 \%$ kroku, jinými slovy v každém kroku bylo z povodí odebráno $5 \%$ půdy jemnozrnné a přidáno $5 \%$ půdy hrubozrnné;

— změna půdního pokryvu: uvažována záměna orné půdy za luční porost, a to v5\% kroku, jinými slovy v každém kroku bylo z povodí odebráno $5 \%$ orné půdy a príiáno 5 \% lučního porostu;

— změna v množství dávkovaných hnojiv: bylo uvažováno odečítání v 10\% kroku od standardního dávkování, dokud dávkování nebylo rovno 0 \% standardní dávky, a naopak přičítání k standardnímu dávkování, dokud dávkování nebylo rovno 200 \% standardní dávky;

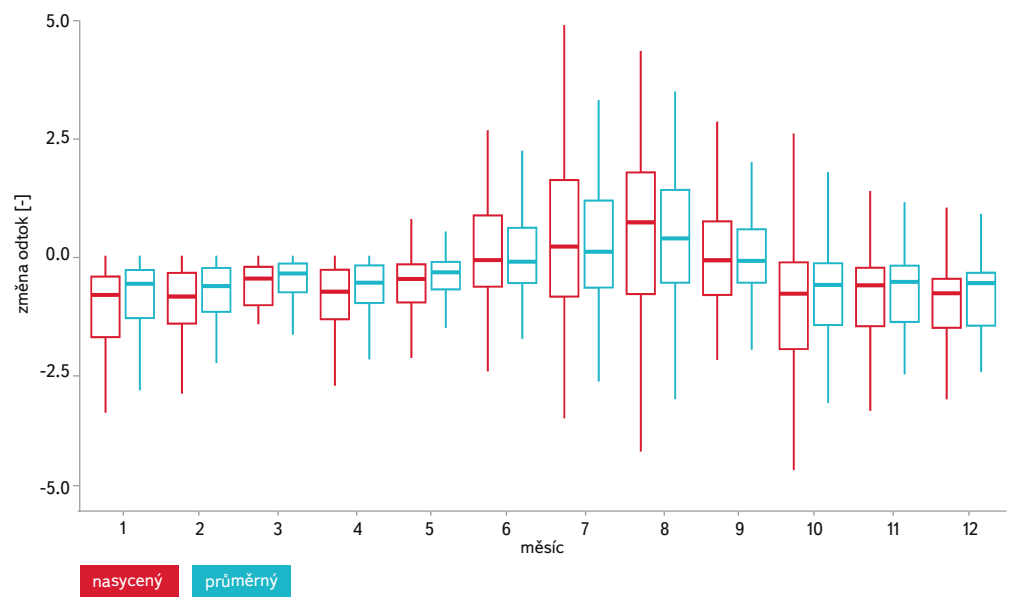

Obr. 10. Změny měsíčních odtokových výšek ve formě box-plotů (před opatřením a po realizaci opatření)

Fig. 10. Changes in the monthly average runoff heights between current state of the catchment and after application of the designed restoration measures

— změna v množství atmosférické (suché i mokré) depozice dusíku: bylo uvažováno odečitání ve 25\% kroku od standardních hodnot atmosférické depozice, dokud depozice nebyla rovna $0 \%$ standardní depozice, a naopak přičítání k standardní hodnotě atmosférické depozice, dokud depozice nebyla rovna $200 \%$ standardní depozice;

— změna teploty ovzduší o $2^{\circ} \mathrm{C}$ : bylo uvažováno zvýšení veškeré vstupní teploty do modelu o $2^{\circ} \mathrm{C}$ (tato změna zavedena za účelem zjištění citlivosti modelu na zvýšení teploty v rámci jakosti vody).

\section{VÝSLEDKY}

Podobně jako v prípadě metodiky jsou zde prezentovány výsledky modelování efektu navržených opatření odděleně pro tři zohledněné aspekty hydrologického chování povodí.

Tabulka 1. Vyhodnocení krátkodobých srážko-odtokových epizod

Table 1. Changes in characteristics of runoff from design short-term rainfall events

\begin{tabular}{|c|c|c|c|c|c|c|c|c|c|c|}
\hline $\mathbf{N}$ & Průběh & Q1 & Q2 & V1 & V2 & T1 & T2 & $\mathbf{d Q}$ & dV & dT \\
\hline roky & - & $\mathrm{m}^{3} / \mathrm{s}$ & $\mathrm{m}^{3} / \mathrm{s}$ & tis. $\mathrm{m}^{3}$ & tis. $\mathrm{m}^{3}$ & hh:mm & hh:mm & $\%$ & $\%$ & $\min$ \\
\hline 2 & C & 4,2 & 0,4 & 29,0 & 5,2 & $14: 40$ & 15:50 & $-90 \%$ & $-82 \%$ & 70 \\
\hline 2 & $E$ & 3,7 & 0,5 & 29,0 & 5,2 & 14:50 & 15:35 & $-87 \%$ & $-82 \%$ & 45 \\
\hline 5 & C & 9,9 & 1,9 & 69,1 & 19,1 & $14: 35$ & $14: 50$ & $-80 \%$ & $-72 \%$ & 15 \\
\hline 5 & E & 8,5 & 1,8 & 69,2 & 19,1 & $14: 35$ & 15:05 & $-78 \%$ & $-72 \%$ & 30 \\
\hline 10 & C & 14,7 & 3,6 & 105,5 & 38,6 & $14: 35$ & $14: 45$ & $-75 \%$ & $-63 \%$ & 10 \\
\hline 10 & E & 12,8 & 3,3 & 105,5 & 38,7 & $14: 30$ & 15:00 & $-74 \%$ & $-63 \%$ & 30 \\
\hline 20 & C & 20,0 & 5,8 & 147,7 & 65,3 & $14: 35$ & $14: 45$ & $-71 \%$ & $-56 \%$ & 10 \\
\hline 20 & $E$ & 17,9 & 5,2 & 147,7 & 65,3 & $14: 25$ & 14:55 & $-71 \%$ & $-56 \%$ & 30 \\
\hline 50 & C & 28,2 & 9,2 & 213,1 & 111,2 & $14: 30$ & $14: 45$ & $-67 \%$ & $-48 \%$ & 15 \\
\hline 50 & E & 25,9 & 8,4 & 213,1 & 111,2 & $14: 20$ & $14: 55$ & $-68 \%$ & $-48 \%$ & 35 \\
\hline
\end{tabular}


20

0

0
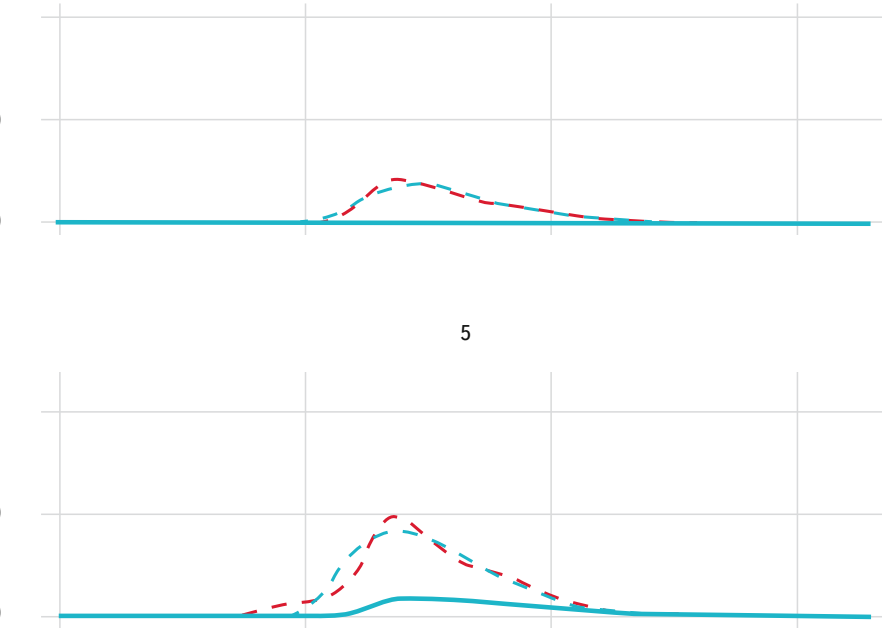

10

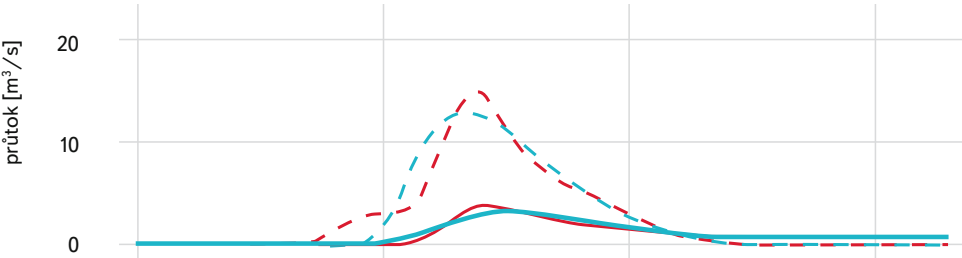

20

20

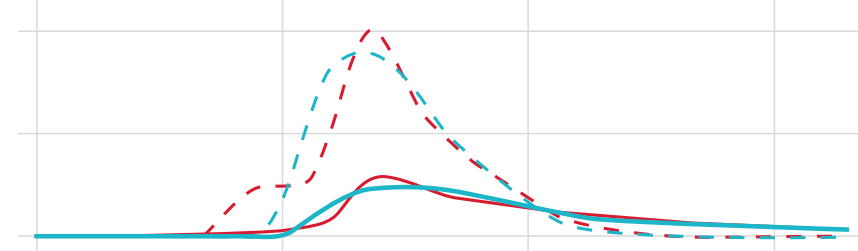

50

20

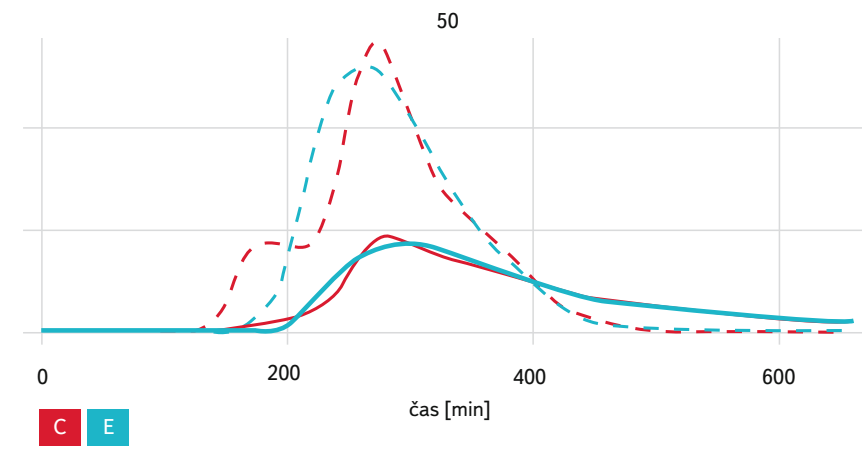

Obr. 11. Návrhové průtoky podle doby opakování pro jednotlivé typy vln (čárkovaně před opatřením, plně po opatření)

Fig. 11. Maximum discharges of different return period resulting from the most frequent patterns of the causal design rainfall; dashed line for the current state of the catchment, dotted line after application of the designed restoration measures

\section{Ovlivnění dlouhodobé hydrologické bilance}

Na obr. 9 jsou vyhodnoceny průměrné odtokové výšky za období 1961-2015 pro danou lokalitu a čtyři scénáre. Na obr. 10 jsou zobrazeny změny odtokových výšek po aplikaci opatření pro průměrný a nasycený stav. Lze pozorovat minimální negativní dopad na dlouhodobý vodní režim a v letních měsících lehký nárůst odtoků.

\section{Ovlivnění extrémních odtoků}

V zájmové lokalitě Olešná byla navržena rozsáhlá organizační a agrotechnická protierozní opatření, revitalizace prakticky všech úseků vodního toku a jedna nová vodní nádrž o rozloze 4,5 ha. Z hlediska průběhů krátkodobých srážek v lokalitě převažují typy $\mathrm{C}$ a E. Ovlivnění odtokové odezvy na extrémní návrhové srážky s těmito průběhy a s dobami opakování 2-50 let ukazuje obr. 11 a procentuální snížení kulminačních průtoků, objemu odtoku do konce simulace a posun kulminace je vyčíslen v tabulce 1 .

Z uvedených grafư a hodnot je patrné, že navržená opatření mají potenciál prakticky zcela zadržet odtokovou odezvu na srážky s dobou opakování 2-5 let. Při extrémnějších událostech zajistí značnou redukci kulminačních průtoků i objemu odtoku v časovém úseku simulace (11 h). Na redukci má nejvýraznější vliv navržená suchá nádrž, jejíž kapacita je srovnatelná s objemem 100leté povodňové viny ze svého dílčího povodí. Hodnoty redukce objemu odtoku $\checkmark$ tabulce 1 jsou ovlivněny krátkou dobou simulace, během níž nebyl dokončen výpočet transformace odtokových vin v suché nádrži. Výsledné redukce objemu je nutné očekávat ve skutečnosti nižší. Z hlediska průběhu návrhových srážek generuje vyšší kulminační odtoky dvouvrcholová návrhová srážka typu C, rozdíl oproti druhému nejčastějšímu průběhu typu E však není výrazný. Podstatně se oba průběhy liší pouze při posuzování zpoždění kulminací způsobených navrženými opatřeními: VInu vyvolanou intenzivnější srážkou typu C zpožd'ují v průměru o 10 minut, zatímco vlny vyvolané rovnoměrnější srážkou typu E jsou zpožděny více, cca o 30 minut oproti stavu povodí bez navržených opatření.

\section{Ovlivnění látkových toků}

Obrázky 12-15 sumarizují citlivostní analýzu a dávají jasnou představu o tom, jaká komponenta modelu má vliv na tu kterou koncentraci modelovaných látek. Na ose Y Ize vidět danou komponentu modelu (adaptační opatření), na ose X pak procentuální změnu dané komponenty, přičemž hodnota (resp. barva) dlaždice udává průměrnou hodnotu změny od výchozí modelované koncentrace. Modrá barva značí pokles od výchozí koncentrace, naopak červená značí nárůst od výchozí koncentrace a bílá barva reprezentuje nulovou změnu.

Hodnotový rozsah je pro každou látku specifický, poněvadž jejich koncentrace $v$ povodích, resp. $v$ tocích je rozdílná. Obecně lze vyvozovat, že s prechodem z jemnozrnné půdy na půdu s hrubší strukturou klesá koncentrace všech čtyř modelovaných látek (jmenovitě anorganický dusík, organický dusík, pevný fosfor a rozpustný fosfor). Přechod z orné půdy na luční porost zaprííciňuje pokles koncentrace dusíku a rozpustného fosforu, nikoliv však pevného fosforu. Dávkování hnojiv má vliv pouze na fosfor v obou fázích a jejich výsledná koncentrace kladně koreluje s mírou dávkování, dusík zůstává neměnný. Stejně tak atmosférická depozice dusíku logicky kladně koreluje s mírou koncentrace dusíku v tocích. Zvýšení teploty $02^{\circ} \mathrm{C}$ způsobuje nárůst pevného fosforu a organického dusíku a naopak pokles rozpustného fosforu a anorganického dusíku. 


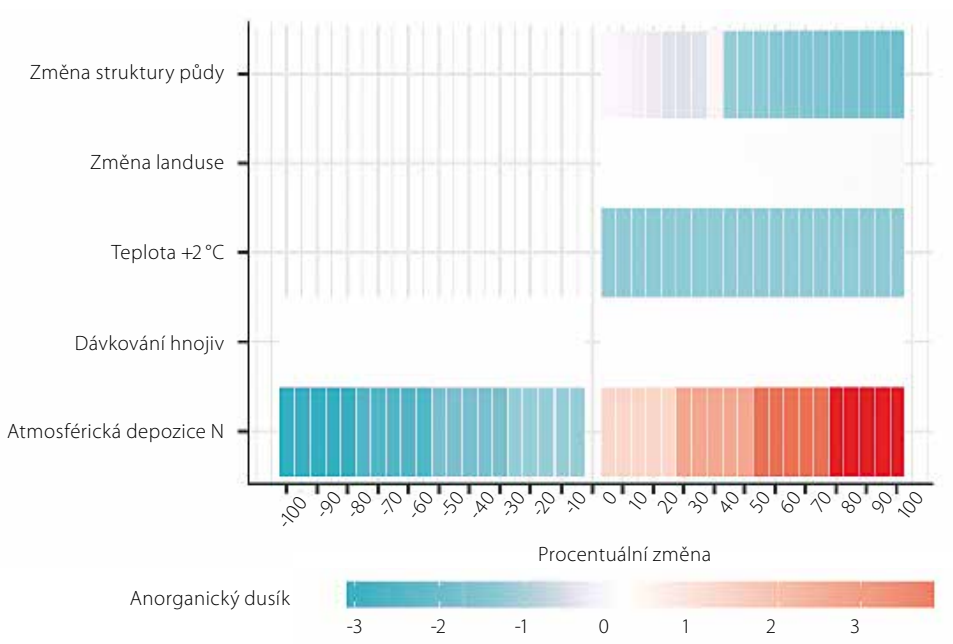

Obr. 12. Modelované změny koncentrací anorganického dusíku

Fig. 12. Simulated changes in the concentration of inorganic nitrogen

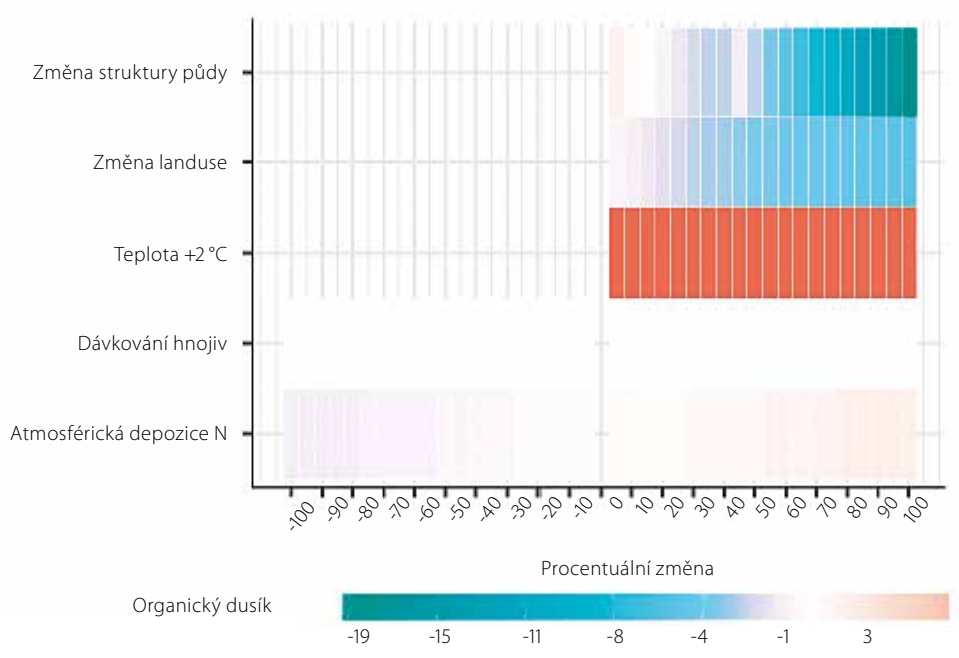

Obr. 13. Modelované změny koncentrací organického dusíku

Fig. 13. Simulated changes in the concentration of organic nitrogen

\section{ZÁVĚR}

Na lokalitě Olešná u Pelhřimova budou mít navržená opatření lehce pozitivní vliv ve srážkově bohatých letních měsících, kdy je zpomalen odtok z území a lehce negativní vliv ve zbytku roku. Změny jsou také dány změnou klimatických veličin, kdy nárůstem teplot roste také potenciální a aktuální evapotranspirace.

Navržená opatření mají potenciál prakticky zcela zadržet odtokovou odezvu na srážky s dobou opakování 2-5 let a i pro extrémnější události zajistí značnou redukci kulminačních průtoků i objemu odtoku, prrípadně jejich zpoždění.

Obecně lze vyvozovat, že s přechodem z jemnozrnné půdy na půdu s hrubší strukturou klesá koncentrace všech čtyř modelovaných látek (jmenovitě anorganický dusík, organický dusík, pevný fosfor a rozpustný fosfor). Přechod z orné půdy na luční porost zapríčinuuje pokles koncentrace dusíku a rozpustného fosforu, nikoliv však pevného fosforu. Dávkování hnojiv má vliv pouze na fosfor v obou fázích a jejich výsledná koncentrace kladně koreluje s mírou dávkování, dusík zůstává neměnný.

$\checkmark$ rámci projektu bylo obdobně posouzeno 20 lokalit a podrobné výsledky jsou dostupné na webových stránkách www.suchovkrajine.cz.

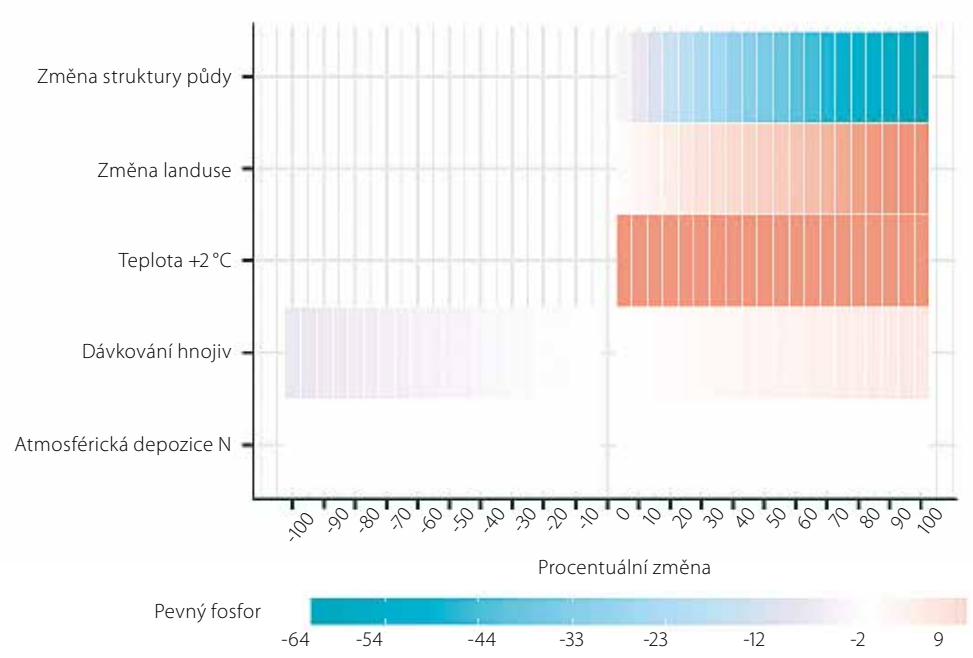

Obr. 14. Modelované změny koncentrací pevného fosforu

Fig. 14. Simulated changes in the concentration of particulate phosphorus

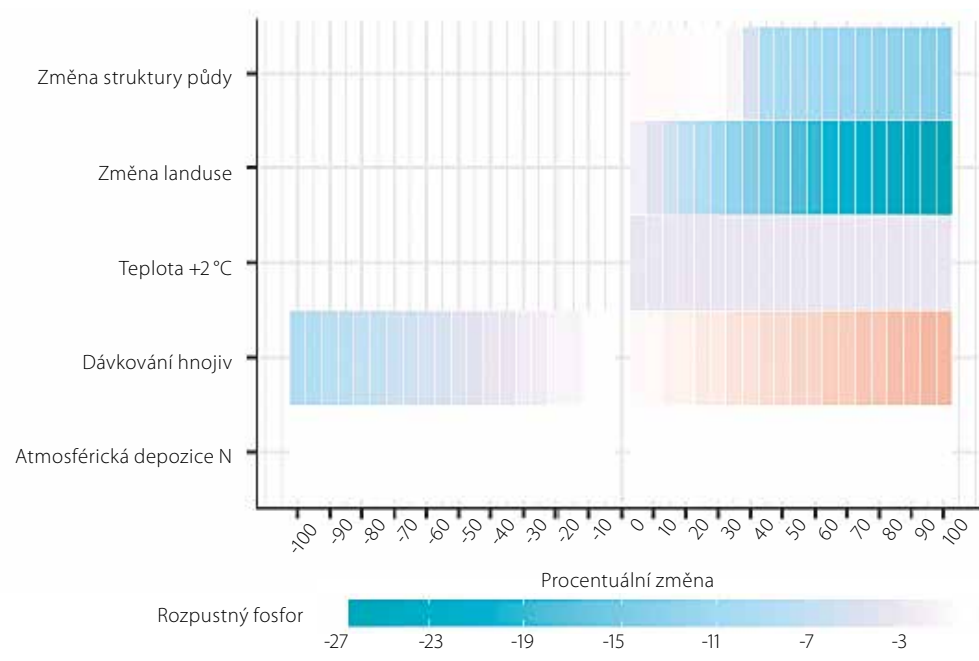

Obr. 15. Modelované změny koncentrací rozpustného fosforu

Fig. 15. Simulated changes in the concentration of dissolved phosphorus

\section{Poděkování}

Príspěvek vznikl v rámci úkolů rešených pro Ministerstvo životního prostředí České republiky a na základě výsledků rưzných výzkumných úkolì. 


\section{Literatura}

[1] KAVKA, P, MÜLLER, M, STROUHAL, L, KAŠPAR, M, BLIŽŇÁK, V, LANDA, M, WEYSKRABOVÁ, L PAVEL, M. a DOSTÁL, T. Krátkodobé srážky pro hydrologické modelováni a navrhováni drobných vodohospodárských staveb v krajině [online], 2018. Dostupné z: http://rain.fsv.cvut.cz

[2] HAVLIKK, A. a FREMROVÁ, L. TNV 752102 Úpravy potoků, 2010.

[3] SCS. Urban hydrology for small watersheds. Technická zpráva. Washington, DC: Engineering Division, Soil Conservation Service, US Department of Agriculture, 1986.

[4] MACKÜ, J. Problematika stanovení hydrologických skupin půd v lesích. In: Krajinné inženýrství 2012, Praha: Ministerstvo zemědělství, 2012, s. 15-22. ISBN 978-80-87384-03-9.

[5] VIZINA, A., HORÁČEK, S. a HANEL, M. Nové možnosti modelu Bilan. Vodohospodářské technickoekonomické informace, 2015, roč. 57, č. 4-5, s. 7-10.

[6] MÁCA, P., BAŠTA, P., KOŽÍN, R. a HANEL, M. Využití geomorfologických charakteristik pro odhad celkové retence povodí. Vodohospodárské technicko-ekonomické informace, 2016, roč. 58, č. 6, s. 54-57.

[7] ŘEZÁČCVÁ, D., PEŠICE, P., and SOKOL, Z. An estimation of the probable maximum precipitation for river basins in the Czech Republic. Atmospheric Research [online], B.m.: Elsevier, 1.9., 2015, vol. 77 , No. 1-4, p. 407-421. ISSN 0169-8095.

[8] MÜLLER, M., KAŠPAR, M., and BLIŽŇÁK, V. Rainfall time structure variability depending on precipitation depths and duration, 2017.

[9] ARHEIMER, B., DAHNÉ, J., DONNELLY, C., LINDSTROM, G., and STROMQVIST, J. Water andnutrient simulations using the HYPE model for Sweden vs. the Baltic Sea basin - influence of input-data quality and scale. Hydrology research, 2012, vol. 43, No. 4, p. 315-329.

\section{Autoři}

Ing. Adam Vizina, Ph.D.,

凶adam.vizina@vuv.cz

Ing. Luděk Strouhal, Ph.D., ${ }^{1,3}$

凶ludek.strouhal@vuv.cz

Ing. Miriam Dzuráková

凶miriam.dzurakova@vuv.cz

Ing. Vojtěch Moravec ${ }^{2}$

凶moravecv@fzp.czu.cz

Ing. Eva Melišová ${ }^{2}$

凶melisovae@fzp.czu.cz

'Výzkumný ústav vodohospodářský T. G. Masaryka, v. v. i. Česká zemědělská univerzita v Praze, Fakulta životního prostředí

${ }^{3}$ České vysoké učení technické, Fakulta stavební

Příspěvek prošel lektorským řízením

\section{STUDY ON THE ASSESSMENT OF THE EFFECT OF NATURE-FRIENDLY MEAS- URES IN THE OLEŠNÁ IN PELHŘIMOV CATCHMENT AREA USING THE BILAN, HEC-HMS AND HYPE MODELS}

\section{VIZINA, A. ${ }^{1,2}$; STROUHAL, L. ${ }^{1,3}$; DZURAKOVA, M. ${ }^{1 ;}$ MORAVEC, V. ${ }^{2}$; MELISOVA, E. ${ }^{2}$}

${ }^{1}$ TGM Water Research Institute, p. r. i.

${ }^{2}$ Czech University of Life Sciences in Prague, Faculty of the Environment ${ }^{3}$ Czech Technical University, Faculty of Civil Engineering

Keywords: natural restoration measures - catchment renaturation hydrologic balance - extreme discharges - nutrient fluxes -

small catchment - hydrological modelling

A catalogue of natural restoration measures was created within several research programs under Ministry of the Environment of the Czech Republic, especially in the program for hydrological draught mitigation. As a next step suitable catchments for their application were identified. With use of hydrological models, the effect of designed restoration measures on three aspects of hydrological regime was assessed. This case study reports the results of this assessment in the Olešná stream catchment located to the east of Pelhřimov, in the central part of the Czech Republic. Changes in the long-term hydrological regime were assessed by the BILAN model using the daily step and more than 30-years long climatological time series. Effect on the extreme discharges was evaluated in the HEC-HMS and potential changes in nutrient fluxes were quantified with the HYPE model in the form of sensitivity analysis. Concerning the hydrological balance, slightly positive effect was identified in the wet summer months, whereas in the rest of the year the changes were rather negative. Extreme discharges with return periods up to 5 years were almost entirely retained by the measures designed, for longer return periods a high potential in reducing the runoff volumes and peak discharges or in delaying the peaks was proven. The sensitivity analysis of nutrient fluxes in HYPE showed, that turning arable land into grassland leads to decrease in concentrations of nitrogen and dissolved phosphorus, but not in solid phosphorus. The fertilizers dosage influences only the concentration of both forms of phosphorus, whereas the nitrogen remains unaffected. 